\title{
ON THE ORIGIN OF THE LATIN DECAD-MORPHEME -gint-
}

In this brief article it is proposed that the problematic - $g$ - of the Latin decad morpheme -gint-derives from a specifically Latin manifestation of the voiced sandhi variant of the Indo-European non-singular marker in ${ }^{*}-k$. This theory is based on some recent research concerning the evolution of the category of number and the system of numerals in Indo-European.

It is well-known that Latin shows a morpheme -gint- which is used to derive decads from 20 to 90 (vigintī '20', trīgintā '30', quadrägintā '40', quīnquāgintà '50', sexāgintà '60', septuāgintā '70', octōgintā '80', nōnaginta ' '90') and (with a vocalic alternate) certain hundreds (quadringent $\bar{i}$ '400', quingent $\bar{i}$ '500', septingenti '700', octingenti ' 800 ', nōngenti '900')'. According to Szemerényi (1960, p. 165), "Among the many problems presented by the Latin system of numerals not the least difficult is the unexpected appearance of $-g$ - in place of IE $k$ in the decadmorpheme -gintä...». In contrast to the Latin form, other dialectal reflexes of this Indo-European etymon clearly reflect a *-k-: Gk. -kovтa, Skt. -sati-, Avest. -saiti, Armen. -sun. Buck (1933, p. 231) simply acknowledges that «there is no adequate explanation of the voiced in place of the voiceless stop in several of the [Latin] numeral forms", but other scholars have attempted diachronic analyses of this matter. Essentially, two positions have emerged in the ensuing debate - the voicing is a specifically Latin development and the voicing has its origin in Indo-European. The first, more recent view has gained widespread acceptance, especially by way of Szemerényi (1960, pp. 165-169). Building on the work of Thurneysen, Szemerényi (1960, pp. 168-169) ultimately derives the Latin suffix from IE ${ }^{*}-k m t\left(>^{*} *_{-k n t}\right)$ and then maintains that «in the hundreds at any rate, $-g$ - appears only in those forms where there

1 According to Buck (1933, p. 231), "The L. int for ent is perhaps due to vowel assimilation in uiginti, whence by analogy also quadrägintä, etc. (in contrast to quadringenti, etc.)", cf. Leumann 1963, p. 293. 
is a complete nasal environment, especially clear at the stage $-n k n-\ldots$ [W]e cannot but conclude that the voicing of $k$ must be due to the surrounding sonants». He ascribes to long sonants "greater voicing force» and thereby concludes that "only this can account for the fact that in ${ }^{*} k$ ueturi- even the preceding voiceless stop became voiced [cf. quadrāgint-], just as in Greek the form ${ }^{*}$ septīn- resulted in $\varepsilon \beta \delta \mu a-$ - while ${ }^{*}$ septm gave $\varepsilon \pi r a ́$. It is possible that in gaining ground the new ending -gint- was helped by the number of voiceless stops with which other decads were endowed. Thus *oktōkint-, placed between septuägint- and nönägint-, may have 'welcomed' the change to octögint-, and likewise *quinquäkint-, under the welcome pressure of quadrägint-».

The second position ascribes the attested dialectal variation to IndoEuropean. Kent $(1946$, p. 79$)$ asserts that «the $-g$ - seems to be an IE variant», maintaining that "in PIE, doublet forms of roots developed, with variations... between voiceless and voiced stops..., cf. [also] päcis and pangö» (1932, pp. 108-109). Meillet and Vendryes (1953, p. 69)

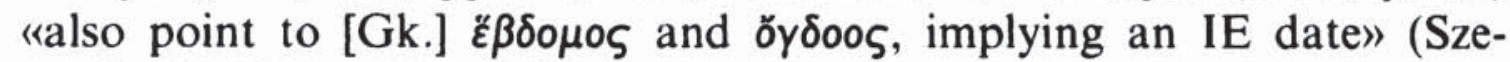
merényi 1960, p. 166, n. 33).

In light of some recent proposals of mine regarding the etymology of Indo-European numerals (Shields 1984, 1985, Forthcoming a, Forthcoming c), I want to present a compromise position - that the appearance of - $g$ - in -gint- is a specifically Latin manifestation of an Indo-European phonological process.

My theory of the origin of the voiced initial of Latin -gint- is based on two hypotheses. First, from an early period Indo-European showed phonological variation involving external sandhi. Among the sandhi rules of early Indo-European was the process by which "voiceless stops and spirants became voiced before voiced consonants... [although] it is by no means certain that they did so before vowels as well» (Ward 1946 , p. 102). In support of this claim, Brugmann (1930, pp. 883-884) cites «"edōd bhrätrai 'er gab dem Bruder' = ai. ádād bhrátre; *tāz dhughateres (dhugdheres) 'diese Tochter' $=$ ai. tấ duhitáras..., ai. sūre duhitá

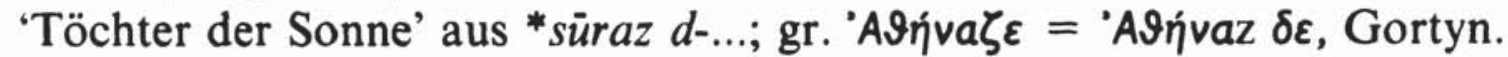

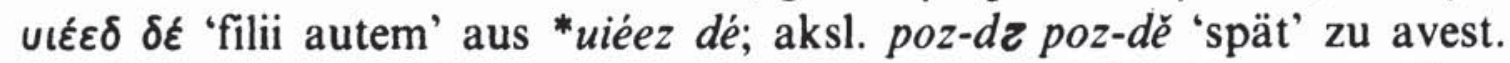
pas-ča lat. pos-t.» Of course, sandhi variants are subject to generalization and/or specialization, especially if the factors which originally conditioned the alternation have become obscured. Shevelov (1965, p. 366) thus notes that after final consonants were lost in all words except prepositions in early Slavic, "with the rules of the outdated IE 'voicing type' of sandhi gradually forgotten, the 'voiced form' of a great many prepositions... was perceived as the basic, normal form... This form of 
preposition in many Sl languages was generalized. This explains why Sl has $i z$ 'from' as a counterpart of Li iš, OPr is-, Gr ḱs, La ex, Ir ess, all with a voiceless final consonant.»

The second hypothesis is that the inflectional category non-singular was a late development in the proto-language. In this regard, Lehmann (1974, pp. 201-202) argues: "The system of verb endings clearly points to an earlier period in which there was no verbal inflection for number... For the dual and plural endings are obviously defective. We cannot reconstruct endings in these two numbers which are as well supported as are those of the singular, except for the third plural... The number system is defective in substantival as well as in verbal inflection, as suppletive paradigms indicate, e.g., Hitt. $u k$ 'I', $u \bar{e} s ̌$ 'we', etc., in contrast with demonstratives, e.g., $k \bar{a} \breve{s}, k \bar{e}$ 'this, these', and nouns, e.g., antuhšaš, antuhšeš 'man, men'... Number accordingly was not consistently applied in late PIE and the early dialects in accordance with natural reference. Subsequently application became more regular, and number congruence was carried out for both substantives and verbs.» The bifurcation of the non-singular category into dual and plural was later still (cf. Adrados 1987, p. 7), as the primitive development of the dual number in Hittite demonstrates (Ivanov 1958, p. 250). The nonsingular (dual/plural) markers of Indo-European, probably originating as enclitic quantitative adverbs (cf. Schmalsteig 1974a, p. 1) or as enclitic deictic particles (cf. Shields Forthcoming b), included such commonly reconstructed elements as *-(e/o)s (nom. pl. Skt. devā́s 'gods', Go. dagōs 'days'; acc. pl. Lat. lupōs, Lith. vilkùs 'wolves') and *-i (nom.

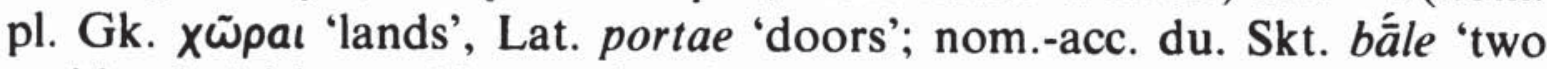
maidens', Lith. ranki 'two hands'; nom.-acc. pl. Hitt. kururi 'hostilities'). Moreover, a non-singular suffix * $-n$ can also be reconstructed on the basis of such Tocharian nominative plurals as AB riñ 'cities' and käntwäñ 'tongues' (cf. Schmalstieg 1980, p. 74), as well as the $o-, i-$, and $u$-stem nominative-accusative dual endings traditionally reconstructed

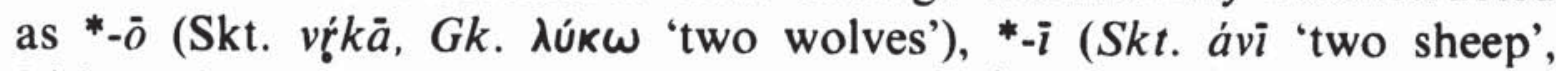

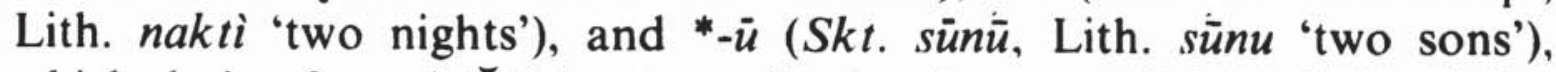
which derive from *- $\breve{V}$ (short vowel) plus *-n according to Schmalstieg 1973 , pp. 147-151; 1974b). The non-singular desinence "*- $n$ is found dialectally in contamination with the non-singular ending *- $t$ in the plural suffix *-nt: Toch. A -nt, -ntu, Toch. B. -nta, Luwian -nzi (nom.), -nza (acc.-dat.). Since the collective is a secondary function of the nonsingular (cf. Shields 1982, pp. 63-64), it is significant that "in Hittite, Indo-Iranian, Slavic and perhaps in Greek we find -nt more or less clearly as a collective suffix according to Erhart (1970, p. 79). Sturte- 
vant (1951, p. 79) cites such forms as an-tu-uh-ša-an-na-an-za 'people' as opposed to an-tu-uh-ša-aš 'man'; ud-ne-ya-an-za, ud-ni-ya-an-za, ud-ne-e$a n-z a$, acc. $u d-n i-a n-d a-a n$ 'population' as opposed to $u d-n e(-e), u d-n i-e$, ud-ni(-i) "country"' (Schmalstieg 1980, p. 75)" (Shields 1985, pp. 190191). I believe that ${ }^{*}-t$, in uncontaminated form, is seen, for example, «in the nominative dual of the personal pronouns of Germanic (OE wit 'we two', OE 3it, Go. *jut 'you two') and possibly Baltic (Lith. [dial.] $v e \tilde{e} u$, mùdu "we two', jùdu 'you two')» (Shields 1981, pp. 42-43). The desinence $^{*}-u$ is evident in nominative-accusative dual forms like Skt. vŕkau 'two wolves', OIr. dau 'two', Go. ahtau 'eight'. Even less productive non-singular morphemes were $*_{-}(e / o) r$, about which Erhart $(1970$, p. 80$)$ says: «Eine andere Pluralendung... liegt vielleicht in den armenischen Formen auf -er, -ear, und in den keltischen (mittelirischen, mittelkornischen) Formen auf -ar vor; alle diese Formen gehen wohl auf ein i.e. $r$-Kollektivum zurück», and ${ }^{*}-k$, a collective suffix about which Kronasser $(1956$, p. 126) remarks: «... dachte man sich... [Gk.]

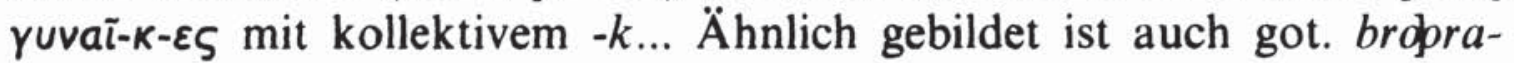
hans 'Gebrüder' (mit *-ko-) neben dem gewöhnlichen Plural broprjus von bropar (vgl. auch an. fedgar 'Vater und Sohn' neben fedir 'Vater' u.a. im Germ.)." "He suggests that 'vielleicht' the Armenian plural marker $-k^{\mathrm{c}}$ (e.g. kanay- $k^{\mathrm{c}}$ 'women') shows this same element (1956, p. 126), but Godel (1975, pp. 102-103) argues strongly against this view, demonstrating that $-k^{\mathrm{c}}$ derives from ${ }^{*}-V s$. More likely cases of dialectal attestation of *-k include "messap. gunakhai, gunaiki [?] et... v.phryg. bonok..." (Perrot 1961, p. 315)» (Shields 1984, p. 77).

In my opinion, the cardinals of Indo-European represent composite forms containing a root to which was subsequently attached, after the emergence of the non-singular category, various non-singular markers as a means of hypercharacterizing their inherent non-singularity. Because of the late appearance of certain of these markers, dialectal variation in the shapes of the cardinals is common. For example, in Shields 1985, p. 196, I write: "The traditional reconstruction of ' 7 ' is *septm (Skt. saptá, Gk. Ėпrá, Lat. septem), although Germanic attests *sepm (Go. sibun, OE seofon, OHG sibun), supposedly derived from *septm through dissimilation (cf. Brugmann 1911, p. 18 and Krahe 1969, p. 89). I believe, however, that the original root for ' 7 ' was *sep- and that this root was extended by the non-singular markers $*_{-} t$ and $*_{-} n$, resulting in the creation of the doublets *sep- $t$ and *sep- $n$. *sep- $n$ early became *sepm as a result of assimilation, and this alternate was eventually contaminated with *sept, yielding *septm. Although both *sepm and *septm are attested, *sept has apparently been replaced entirely by these other 
forms." Likewise, in Shields Forthcoming c, I propose that IE *kue-

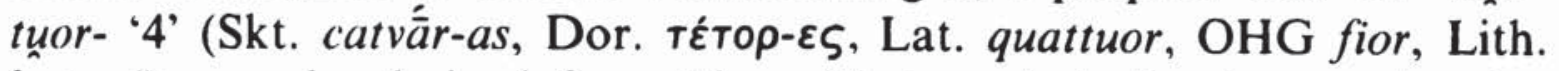
$k e t u r-i)$ "can be derived from * $k$ ue- 'that one' $+^{*}-t$ (a non-singular marker), hypercharacterizing the non-singularity of ' 4 ', $+{ }^{*}-u$ (a nonsingular [ $>$ dual] marker), perhaps emphasizing the paral nature of '4', $+{ }^{*}$-or (a non-singular [ $>$ collective] marker), perhaps emphasizing that ' 4 ' constitutes a collection of pairs ${ }^{2}$. IE *kuetuor- can thus be assigned the etymological meaning 'those ones in pairs together'." Similarly, in Shields 1984, I follow Peeters (1978) in reconstructing the origi-

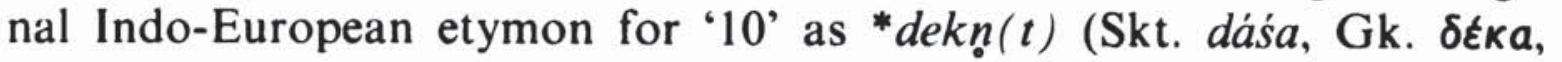
Lat. decem, Go. taihun, Lith. dešimt, OCS desętz) and then propose that, etymologically, it "represents ${ }^{*} d e$ ' 2 ' $+{ }^{*}-k$ (a collective suffix...) + [the non-singular suffix] ${ }^{*}-n+$ [the non-singular marker] $\left.{ }^{*}-t\right)$ (Shields 1985 , p. 197), "yielding still another occurrence of the non-singular ending *-nt» at least in some dialects (Shields 1985, p. 193).

I want to emphasize that the item ${ }^{*} \operatorname{dekn}(t)$ is to be connected etymologically with *kntom (or *kmtom) '100', cf. Brugmann 1911, p. 29, Meillet 1964, pp. 413-414, Szemerényi 1960, p. 139, Justus 1988, p. 522, even though the nature of the relationship is not clear. Traditional historical Indo-European theory posits that the two items are ablaut variants of ${ }^{*}(d) k n t$, with loss of $d$ in initial consonant cluster; but this is not a necessary assumption. I would rather explain *knt-om as the result of a morphological resegmentation of * $\operatorname{dekn}(t)$, similar to the process through which was derived ModE. burger from hamburg-er ( $>$ ham-burger), cf. Lehmann 1973, pp. 193-194 (see Shields 1984 for further details). I also want to emphasize that ${ }^{*} \operatorname{dekn}(t)$ did not originally possess the meaning ' 10 ' and that * $k n t-o m$ did not originally have the signification '100'; instead, both constituted what Menninger (1969, p. 15) calls "the limit of counting», the upper bound of a numerical system to which can be loosely ascribed the meaning 'many'. Only later were these items assigned more specific numerical values as a result of semantic reinterpretation motivated by «changes which successively increased the limit number" (Justus 1988, p. 527). I support this conclusion in Shields 1984 by citing typological evidence, while Justus (1988) independently reaches the same conclusion in light of the range of meanings attested by the dialectal reflexes of the forms, cf. from PIE

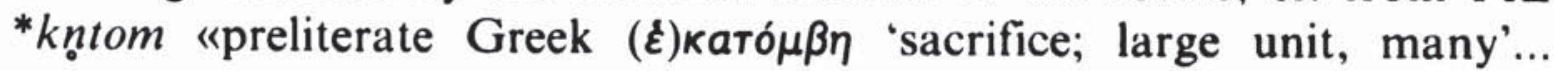
PAnat kon-to 'unit of measurement': Lycian sñta 'unit'. PAnat kom-io'all, whole': Lycian cĩme 'five', Hittite humant 'all'» (1988, p. 526).

${ }^{2}$ Beekes (1987), too, argues that the element ${ }^{*}-e /$ or- of this numeral is an occurrence of the collective marker in ${ }^{*}-r$. 
Now Latin -gint- and other related dialectal forms derive ultimately from * (de)knt, cf. Buck 1933, p. 231, Burrow 1973, p. 262, Szemerényi 1980, pp. 206-207. If it is true that ${ }^{*} \operatorname{dekn}_{0}(t)$ itself is a composite form which, at one point in time, appeared simply as *de- $k$, then it is reasonable to assume the existence of a sandhi variant in ${ }^{*} d e-g$. To both forms was added the non-singular marker ${ }^{*}-n$, yielding ${ }^{*}$ dekn and *degn. Latin -gint- may very well show the generalization of the morphological alternate resulting from the resegmentation of the voiced doublet (i.e. $\left.{ }^{*} g n[t]\right)$, demonstrating a peculiar dialectal development of the results of a regular Indo-European phonological process and a subsequent Indo-European irregular (non-proportional) analogical change. It is interesting that "while the cardinal decads all have -ginta the ordinals and their associates (multiplicatives and distributives) we have uicésimus, tricèsimus etc.» (Szemerényi 1960, p. 166). Thus, even Latin attests reflexes of both inherited doublets, despite its tendency to specialize the voiceless variant in secondary formations. Since Latin does attest both inherited sandhi variants, which only gradually underwent analogical extension and functional specialization, it is difficult to discern any validity in Szemerényi's argument that the existence of ordinals in $-k$ precludes the voicing of $-k$ uin IE times since the ordinals etc., as derivative forms would in that case likewise show the voicing" $\left(1960\right.$, p. 166). Early Latin apparently inherited both ${ }^{*} k n(t)$ and ${ }^{*} g n(t)$, with the former coming to serve as the basis for the ordinals. The fact that the attested distribution of doublet forms results from still further analogical reformulation of items ultimately derived from a basically phonological process explains the irregular pattern of occurrence.

Such a specialization of voiced doublet forms as primary morphological exponents is not an isolated phenomenon in Latin. After noting the existence of many other voiced/voiceless doublets in Indo-European (e.g., Lat. sub, Go. uf), Szemerényi (1973) emphasizes the Latin (and, less frequently, the Celtic and Germanic) preference for the voiced variant as the unmarked member of the pair (e.g., OLat. 3rd sg. sec. $-d$ vs. Skt. 3rd sg. sec. - $t$ [with a sandhi variant $-d$ ], cf. Szemerényi 1973, p. 61 ). It is interesting that Greek, too, attests a similar voicing alternation

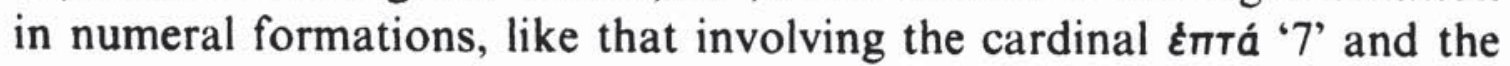
ordinal है $\beta \delta о \mu о \zeta ~ ' 7 t h$ ', which probably derive from the sandhi variants *sep and *seb, respectively. Indeed, the Latin voicing of $-t$ - in quad-rä(gintā) '40', quad-rin-(genti) ' 400 ' may also be explained as resulting from an original sandhi variation between ${ }^{*} k w e-t$ and ${ }^{*} k w e-d^{3}$.

${ }^{3}$ The unexpected voiced consonants in Gk. $\delta \gamma \delta 00 \varsigma$ ' 8 th' (cf. $\delta \times T \omega$ ' ' 8 ') can be explained in the same manner. The voiced sandhi variant of the root ${ }^{*} o k$ - has been ex- 
Of course, it is impossible to prove the absolute validity of any of the theories about the etymology of -gint-. However, I believe that the proposal made here is as reasonable as any previously articulated and, as such, should be given serious consideration as an etymological explanation.

Kenneth Shields, JR.

\section{REFERENCES}

Adrados, Francisco R. (1987): «Binary and Multiple Oppositions in the History of Indo-European", Festschrift for Henry Hoenigswald, ed. by G. Cardona and N. Zide, Tübingen, Günter Narr Verlag, pp. 1-10.

Beekes, Robert S. P. (1987): "The Word for 'Four' in Proto-Indo-European», Journal of Indo-European Studies 15, pp. 215-220.

Brugmann, Karl (1911): Grundriss der vergleichende Grammatik der indogermanischen Sprachen, vol. II 2, Strassburg, Trübner.

- (1930): Grundriss der vergleichende Grammatik der indogermanischen Sprachen, vol. II 3, Strassburg, Trübner.

Buck, Carl (1933): A Comparative Grammar of Greek and Latin, Chicago, University Press.

Burrow, T. (1973): The Sanskrit Language, rev. ed., London, Faber and Faber.

Erhart, Adolf (1970): Studien zur indoeuropäischen Morphologie, Brno, Opera Universitatis Purkynianae Brunensis Facultas Philosophica.

Godel, Robert (1975): An Introduction to the Study of Classical Armenian, Wiesbaden, Ludwig Reichert Verlag.

Ivanov, V. V. (1958): "The Importance of New Data Concerning Hittite and Tocharian Languages for the Comparative Historical Grammar of IndoEuropean Languages", Proceedings of the Eighth Congress of Linguists, ed. by E. Sivertsen, Oslo, University Press, pp. 611-614.

Justus, Carol (1988): «Indo-European Numerals and Numeral Systems», A Linguistic Happening in Memory of Ben Schwartz, ed. by Y. Arbeitman, Louvain-la-Neuve, Peeters, pp. 516-542.

Kent, Roland (1932): The Sounds of Latin, Baltimore, Waverly Press.

- (1946): The Forms of Latin, Baltimore, Linguistic Society of America.

Krahe, Hans (1969): Germanische Sprachwissenschaft, vol. II, Berlin, de Gruyter.

Kronasser, Heinz (1956): Vergleichende Laut- und Formenlehre des Hethitischen, Heidelberg, Winter.

Lehmann, Winfred (1973): Historical Linguistics: An Introduction, 2nd ed., New York, Holt, Rinehart and Winston.

- (1974): Proto-Indo-European Syntax, Austin, University of Texas Press.

Leumann, Manu (1963): Lateinische Laut- und Formenlehre, Munich, Beck'sche.

tended by the voiced sandhi variant of the non-singular suffix *-t, i.e. ${ }^{*} \operatorname{og}-d$. In regard to this ordinal, Buck (1933, p. 233) merely observes: «... the precise phonetic development is obscure.» 
Meillet, A. (1964): Introduction à l'étude comparative des langues indo-européennes, University of Alabama Press.

- and J. Vendryes (1953): Traité de grammaire comparée des langues classiques, Paris, Champion.

Menninger, Karl (1969): Number Words and Number Symbols: A Cultural History of Numbers, trans. by P. Broneer, Cambridge, Mass., M.I.T. Press.

Peeters, Christian (1978): «Indo-European ${ }^{*} \mathrm{~km} t o m$ or $k n t o m$ ? A Comparative Dilemma", Zeitschrift für vergleichende Sprachforschung 92, pp. 27-28.

Perrot, Jean (1961): Les dérivés latins en -men et -mentum, Paris, Klincksieck.

Schmalstieg, William (1973): "New Thoughts on Indo-European Phonology", Zeitschrift für vergleichende Sprachforschung 87, pp. 99-157.

- (1974a): "Dual and Plural», Unpublished Ms.

- (1974b): «Some Morphological Implications of the Indo-European Passage of ${ }^{*}-o N$ to ${ }^{*}-\bar{m}$, Zeitschrift für vergleichende Sprachforschung 88, pp. 187198.

- (1980): Indo-European Linguistics: A New Synthesis, University Park, Penn State Press.

Shevelov, George (1965): A Prehistory of Slavic, New York, Columbia University Press.

Shields, Kenneth (1981): «The IE Suffix *-t», Balkansko Ezikoznanie 24, 4, pp. 39-46.

- (1982): Indo-European Noun Inflection: A Developmental History, University Park, Penn State Press.

-(1984): «IE *dekm(t) '10’: A New Etymology», Balkansko Ezikoznanie 27, 4, pp. $75-80$.

- (1985): «Speculations about the Indo-European Cardinals 5-10», Diachronica 2, pp. 189-200.

- (Forthcoming a): "Some Comments about the Hittite Numeral ' 3 ', The Asian Minor Connexion: Memorial Offerings for Charles Carter in Anatolian and Other Asian Minor Languages, ed. by Y. Arbeitman, Berlin, Mouton de Gruyter.

- (Forthcoming b): «The Emergence of the Non-Singular Category in IndoEuropean", Lingua Posnaniensis.

- (Forthcoming c): "The Indo-European Numeral '4': A New Etymology», Studia Etymologica Indoeuropaea: Memoriae A. J. Van Windekens, ed. by L. Isebaert, Louvain-la-Neuve, Peeters.

Sturtevant, Edgar (1951): A Comparative Grammar of the Hittite Language, rev. ed., New Haven, Yale University Press.

Szemerényi, Oswald (1960): Studies in the Indo-European System of Numerals, Heidelberg, Winter.

- (1973): «Marked-Unmarked and a Problem of Latin Diachrony», Transactions of the Philological Society, pp. 55-74.

(1980): Einführung in die vergleichende Sprachwissenschaft, 2nd ed., Darmstadt, Wissenschaftliche Buchgesellschaft.

Ward, Ralph (1946): "The Loss of Final Consonants in Greek», Language 22, pp. 102-108. 